\title{
EVALUATION OF SAFETY MANAGEMENT SYSTEMS IN THE TURKISH GROUND HANDLING AND AIRPORT TERMINAL COMPANIES
}

\author{
TÜRKIYE YER HIZMETI VE HAVALIMANI TERMINAL İ̧SLETMELERINDDE \\ EMNIYET YÖNETIM SISTEMİ UYGULAMALARININ DEĞERLENDİRILMESİ
}

\section{Yeșim KURT ${ }^{1}$ \\ Ender GEREDE ${ }^{2}$}

\section{Öz}

$\mathrm{Bu}$ araştırmanın konusu, hava taşımacılığı faaliyetlerinin emniyetinin artırılması ve bu faaliyetlerin kabul edilebilir risk seviyelerinde sürdürülmesi için 2000'li yılların başlarında havacılık otoriteleri tarafından gündeme getirilen Emniyet Yönetim Sistemi (EYS) uygulamalarıdır. EYS havacılık faaliyetlerinin emniyetli bir şekilde sürdürülebilmesi amacıyla ortaya çıkmıș ve kısa sürede hem ulusal hem de uluslararası alanda yayılım göstermiş yönetsel bir uygulamadır. Havacılık sektörü içinde faaliyet gösteren birçok örgütün EYS uyguladıkları ve bünyelerinde EYS bölümleri oluşturduğu görülmektedir. Araştırmanın amacı, Türkiye'deki havacılık örgütlerinin alanda hızla yayılım gösteren EYS'ye geçiş sürecini açıklamaktır. Çalışmada nitel araştırma yöntemi kullanılmıştır. Veri toplama yöntemi olarak yarı yapılandırılmıș görüşmeler, gözlemler ve araștırmacı günlüğünden yararlanılmıștır. Yarı yapılandırılmış görüşmeler amaçlı örneklem yöntemiyle seçilmiş olan, Türkiye'deki A grubu ruhsat sahibi yer hizmeti örgütleri ile yer hizmetleri kapsamında faaliyet gösteren ikram kuruluşları ve terminal örgütlerinden oluşan toplam 11 örgütün EYS yöneticileri ile gerçekleştirilmiştir. Araştırmaya ilgili tüm tarafları dahil edebilmek adına alanda düzenleyici ve denetleyici otorite rolünde olan Sivil Havacılık Genel Müdürlüğ̈̈’nden 1 EYS denetçisi ile de yarı yapılandırılmış görüşme gerçekleştirilmiştir. Araştırma boyunca EYS ile ilgili 3 farklı gözlem gerçekleştirilmiştir. Nitel verilerin analiz edilmesinde tümevarımsal analiz yöntemi kullanılmıştır. Araştırma sonucunda, araştırma alanına dahil edilen örgütlerin EYS'ye geçiş süreci, bu süreçte yaşadıkları zorluklar ve kolaylıklar tartışılmaktadır. Araştırmada son olarak, sürecin iyileştirilmesi için öneriler sunulmaktadır.

Anahtar Kelimeler: Havacılık Emniyeti, Emniyet Yönetim Sistemi, Havacılık Sektörü

\begin{abstract}
This study focuses on the Safety Management System (SMS) brought forward by aviation authorities in the early 2000 s, which aims to increase the safety level of air transportation activities and to maintain these activities at acceptable risk levels. SMS is an administrative application that emerged to ensure safety in aviation activities, and became widespread in national and international fields. Many organizations in the aviation industry implement SMS and set up SMS divisions. The aim of this study is to explain the process of transition to SMS in aviation organizations in Turkey. Qualitative research method was applied. Semi-structured interviews, observations and researcher diary were used as data collection tools. Semi-structured interviews were conducted with 11 organizations' SMS managers who work for group a ground service organizations, catering organizations and terminal organizations. To include all related stakeholders, a semi-structured interview was conducted with an SMS auditor from the Directorate General of Civil Aviation. Three observations related to SMS were performed throughout the research. Qualitative data were analyzed by inductive analyses method. This study discusses organizations' transition to SMS, and the factors that challenge and facilitate the transition process. Lastly, suggestions for process improvements were presented.
\end{abstract}

Keywords: Aviation Safety, Safety Management System, Aviation Industry

\footnotetext{
${ }^{1}$ Anadolu Üniversitesi, Havacılık ve Uzay Bilimleri Fakültesi, Havacılık Yönetimi Bölümü, yesimkurt@anadolu.edu.tr

${ }^{2}$ Anadolu Üniversitesi, Havacılık ve Uzay Bilimleri Fakültesi, Havacılık Yönetimi Bölümü, egerede@anadolu.edu.tr
} 


\section{INTRODUCTION}

Safety Management System (SMS) is an important safety management approach introduced in the early 2000s with a view to improving safety in activities related to air transportation and to maintain such activities at acceptable risk levels. Although air transportation is today the safest mode of transport, there have still been aviation accidents and fatalities. The Malaysia plane crash of March 8, 2014, in which 239 passengers and crew members were lost, the TransAsia accident of February 4, 2015 in Taiwan, in which 47 people lost their lives, and the Germanwings accident of March 24, 2015 in France, in which 144 people lost their lives, indicate that aviation accidents have not been prevented yet.

SMS is a safety management approach implemented to improve safety in aviation activities and to maintain these activities at acceptable risk levels. Aviation authorities acknowledged in the early 2000 s that compliance with rules and regulations was not enough to guarantee safety, and brought up SMS, which is the product of a paradigm that was quite different from safety management approaches adopted in the past. Safety Management Manual, the first reference book related to aviation safety, was published by the International Civil Aviation Authority (ICAO) in 2006 (ICAO, 2006).

SMS is the product of a paradigm shift that sees the world as it is, and acknowledges the fact that humans and organizations can make errors and violations. SMS aims to disclose the root causes of accidents, does not adopt a denouncing approach, and points to the need for a positive safety culture. The main purpose of SMS is to enhance safety performance under real-life conditions. SMS, quite different from old-school safety approaches, encourages all employees to see safety as a priority and to take all steps in flight operation based on this priority. Thus, hazards that are likely to influence each other and cause undesirable incidents may be anticipated, risks of such hazards are determined, and risks are prevented before they cause incidents in order to improve safety in aviation activities. This study aims to investigate the process of transition to SMS, which is seen as a highly important instrument for improving aviation safety. To this end, the study seeks answers to following questions:

1- How was the process of transition to SMS in Turkey?

2- What were the factors that challenged and facilitated the process of transition to SMS in Turkey?

\section{LITERATURE REVIEW}

\subsection{Safety Management System}

There are numberless interactions and hazardous situations caused by interactions not only in the aviation sector but also in human activities of daily living. Thus, by the nature of living, risks cannot be reduced to zero (ICAO, 2009, p. 2-2, 7-13). That is why it is important to keep risks at acceptable levels. The concept of safety corresponds to keeping risks at acceptable and minimal levels (Transport Research Board, 2009: 4, ICAO, 2009, p. 2-2). In the aviation sector as well, there is a need to minimize risks and keep them at acceptable levels. It is possible to fulfill this necessity with Safety Management System, recommended by international aviation authorities. A paradigm shift underlies the safety management approach. The paradigm shift was from the approach based on compliance with regulations to the performance-based approach (Transport Research Board, 2009, p. 7; Maher, 2013).

With regard to aviation safety, the traditional safety management approach resorts to legislations to picture an ideal world order (ICAO, 2006, p. 1-6), and assumes that compliance with regulations ensures the improvement of safety, adopting a perspective that sees the world as it ought to be. However, it has been observed that despite measures, regulations and audits, 
aviation accidents and fatalities continued to happen, and safety could be enhanced to a certain level, but not to the maximum level (ICAO, 2006, p. 1-6; Maher et al., 2013, p. 2); the growing air traffic has brought about new interactions (Transport Research Board, 2009, p. 7); and such interactions lead to the factors that underlie accidents by the nature of living (Perrow, 1984, p. 17-20). As a result of this, a new paradigm has developed, asserting that compliance with regulations does not eliminate risks and is not enough to improve safety. With this paradigm, the ICAO introduced a performance-based approach to safety management (2006, p.1-6-7).

There are several organizations that regulate aviation sector at the national and international level. The ICAO, with 191 member countries, is the largest aviation authority that regulates air transportation. The ICAO, taken as a reference in this study, defined 12 elements that fall under four main components in order to draw the framework of Safety Management System (ICAO, 2006, p. 7-Appendix 2-2; ICAO, 2009, p. 8-3; 2013a, p. 5-2; 2013 b, p. App 2-1), and specified a four-step approach to the implementation of SMS (ICAO, 2009, p. 10-1).

\subsection{Relevant Studies}

SMS, as a rapidly spreading approach among aviation organizations in the sector, has also drawn the interest of researchers and become a topic of research from various perspectives. In their study on safety culture and Safety Management System in aircraft maintenance organizations, Mcdonald et al. (2000) collected data from four maintenance organizations through documents, interviews and questionnaires, and found out that there was no significant difference between these organizations with regard to compliance with tasks and procedures, and that only one organization was different from the others in terms of safety attitudes, in which there was a strong and homogeneous relationship between technicians. In a study focusing on the perceptions of safety, safety violations and improvement of aviation safety, the researchers collected data through focus groups and email questionnaires, pointed to the importance of reporting processes, human resources management and role of the civil aviation authority for the improvement of safety, and discovered that both personal and financial factors play a role in safety violations (Gill, 2004). A study on employees' perceptions of safety management and culture in the aviation sector of New Zealand drew attention to employees' safety responsibilities and the need for enhancing positive safety culture (Gill and Shergill, 2004). In a study collecting data from the Taiwanese aviation industry to establish an effective SMS for aviation organizations, a model proposal was developed to enhance safety culture of personnel and to raise their awareness of organizational identity (Liou et al., 2008). In a study conducted in Turkey to seek possible challenges to the implementation of SMS in aircraft maintenance organizations, the data collected through open-ended questionnaires and analyzed by qualitative methods showed that a positive safety culture played a significant role in the implementation of SMS (Gerede, 2014). Gerede (2015) adopted a different method to seek an answer to the same question, and revealed that a weak positive just culture was the most important challenge to the successful implementation of SMS. The survey of literature provided no research on the process of transition to SMS of aviation organizations in the national context. Thus, this study is particularly important for successful implementation of SMS and improvement of aviation safety.

\section{METHOD}

The aim of this study is to explain the process of transition to SMS in aviation organizations. To this end, the qualitative research design that allows in-depth data collection 
was adopted. This method enables researchers to address why and how rather than what and to which extent aspects of a new situation (Hays and Singh, 2012, p. 4). For the purpose of this study, semi-structured interviews, observation notes and research diary were used, which are all qualitative data-collecting tools. Before semi-structured interviews based on openended questions (Patton, 2002, p. 17), two pilot studies were conducted with safety managers in order to evaluate research and interview questions (Glesne, 2013, p. 74-75). Table 1 and Table 2 present information related to the pilot studies and semi-structured interviews conducted for the purpose of this research.

Table 1. Pilot Study Table

\begin{tabular}{c|c|cc}
$\begin{array}{c}\text { Code } \\
\text { Name }\end{array}$ & Position & Date & Duration \\
\hline$P 1$ & SMS Manager/ Academic & 30.04 .2014 & $16 \mathrm{~min}$. \\
\hline$P 2$ & SMS Manager / Academic & 08.05 .2014 & $39 \mathrm{~min}$. \\
\cline { 2 - 4 }
\end{tabular}

Table 2. Semi-Structured Interview Data Collecting Table

\begin{tabular}{c|c|c|c|c|}
$\begin{array}{c}\text { Code } \\
\text { Name }\end{array}$ & \multicolumn{1}{c}{ Date } & \multicolumn{1}{c}{ Time } & \multicolumn{1}{c}{ Duration } & \multicolumn{2}{c}{ Data Collecting Mode } \\
\hline$P 1$ & 05.01 .2015 & 10.00 & $51 \mathrm{~min}$. & $\begin{array}{c}\text { Interview and voice } \\
\text { recording }\end{array}$ \\
\hline$P 2^{3}$ & 05.01 .2014 & 10.00 & $51 \mathrm{~min}$. & $\begin{array}{c}\text { Interview and voice } \\
\text { recording }\end{array}$ \\
\hline$P 3$ & 05.01 .2015 & 13.00 & $40 \mathrm{~min}$. & $\begin{array}{c}\text { Interview and voice } \\
\text { recording }\end{array}$ \\
\hline$P 4$ & 06.01 .2015 & 10.00 & $55 \mathrm{~min}$. & $\begin{array}{c}\text { Interview and voice } \\
\text { recording }\end{array}$ \\
\hline$P 5$ & 08.01 .2015 & 13.00 & $43 \mathrm{~min}$. & $\begin{array}{c}\text { Interview and voice } \\
\text { recording }\end{array}$ \\
\hline$P 6$ & 19.01 .2015 & 13.00 & $32 \mathrm{~min}$. & $\begin{array}{c}\text { Interview and voice } \\
\text { recording }\end{array}$ \\
\hline$P 7$ & 20.01 .2015 & 10.00 & $47 \mathrm{~min}$. & $\begin{array}{c}\text { Interview and voice } \\
\text { recording }\end{array}$ \\
\hline$P 8$ & 22.01 .2015 & 11.00 & $82 \mathrm{~min}$. & $\begin{array}{c}\text { Interview and voice } \\
\text { recording }\end{array}$ \\
\hline$P 9$ & 22.01 .2015 & 17.30 & $21 \mathrm{~min}$. & $\begin{array}{c}\text { Interview and voice } \\
\text { recording }\end{array}$ \\
\hline$P 10$ & 07.02 .2015 & 11.00 & $67 \mathrm{~min}$. & $\begin{array}{c}\text { Interview and voice } \\
\text { recording }\end{array}$ \\
\hline$P 11$ & 09.02 .2015 & 14.30 & $38 \mathrm{~min}$. & $\begin{array}{c}\text { Interview and voice } \\
\text { recording }\end{array}$ \\
\hline$P 12$ & 10.02 .2015 & 14.00 & $73 \mathrm{~min}$. & $\begin{array}{c}\text { Interview and voice } \\
\text { recording }\end{array}$ \\
\hline$P 13$ & 22.05 .2015 & 15.00 & $53 \mathrm{~min}$. & $\begin{array}{c}\text { Interview and voice } \\
\text { recording }\end{array}$ \\
\hline
\end{tabular}

${ }^{3}$ The participants with code names $\mathrm{P} 1$ and $\mathrm{P} 2$ took part in the interview together to represent the same organization. 
Observations, like interviews, are data-collecting methods used in qualitative research (Merriam, 1998, p. 94-96; Creswell, 2013, p. 190-191). That is why the researcher participated as an observer in three meetings - one at the aviation organization, one at the national organizations and one at the international organizations level - where challenges and ideas related to SMS were discussed, and took field notes to collect data (Glesne, 2013, p. 9, 87). Table 3 provides information related to three observations made for the purpose of this research.

Table 3. Observation Table

\begin{tabular}{|c|c|c|c|c|c|}
\hline No. & Date & Duration & Place & Subject & $\begin{array}{c}\text { Mode of } \\
\text { Observation }\end{array}$ \\
\hline 1 & $06-10.01 .2014$ & $\begin{array}{c}\text { Five } \\
\text { days }\end{array}$ & Istanbul & $\begin{array}{c}\text { Training on Safety } \\
\text { Management System }\end{array}$ & $\begin{array}{c}\text { Observer as an } \\
\text { participant }\end{array}$ \\
\hline 2 & $19-20.02 .2014$ & $\begin{array}{c}\text { Two } \\
\text { days }\end{array}$ & Ankara & $\begin{array}{c}\text { State Safety Program } \\
\text { Practices (SSP) and } \\
\text { SMS Workshop }\end{array}$ & $\begin{array}{c}\text { Observer as an } \\
\text { participant }\end{array}$ \\
\hline 3 & 09.05 .2014 & One day & Ankara & $\begin{array}{c}\text { Workshop on Safety } \\
\text { Management System }\end{array}$ & $\begin{array}{c}\text { Observer as an } \\
\text { participant }\end{array}$ \\
\hline
\end{tabular}

It is a common sampling method in qualitative research to select cases and participants based on the purpose of study and knowledge of individuals to make an in-depth analysis (Patton, 2002, p. 243; Hays and Singh, 2012, p. 8). In purposive sampling, the researcher selects experts with knowledge, experience and position that represent the population in the best way (Berg, 2001, p. 32; Ary et al., 2010, p. 156). In this study, in accordance with purpose of the study, interviews were conducted with 12 managers that play a role in the implementation of SMS in 11 organizations, and a technical auditor from the

Civil aviation authority with a view to including the other party of SMS implementation into the study. The aviation organizations included in this study are shown in Table 4, and the demographic data related to the participants are presented in Table 5, Table 6.

Table 4. The Organizations Participating in the Research

Enterprises

\begin{tabular}{|c|l|}
\hline 1 & Directorate General of Civil Aviation \\
\hline 2 & Sabiha Gökçen Airport Investment Development and Operation Inc. \\
\hline 3 & TAV Istanbul Atatürk International Airport Terminal Operation Inc. \\
\hline 4 & TAV Esenboğa Investment Development and Operation Inc. \\
\hline 5 & Fraport IC İçtaş Antalya Airport Terminal Operation and Investment Inc. \\
\hline 6 & Mondial Milas Bodrum Airport International Terminal Operation and Investment Inc. \\
\hline 7 & Turkish Airlines DO-CO Catering Services Inc. \\
\hline 8 & Sancak Inflight Services Inc. \\
\hline 9 & LSG Sky Chefs Aviation Services Inc. \\
\hline 10 & Turkish Ground Services TGS Inc. \\
\hline 11 & Airport Ground Services Inc. \\
\hline 12 & Çelebi Airport Services Inc. \\
\hline
\end{tabular}


Table 5. Distribution of Participants by Age Group

\begin{tabular}{|c|r|}
\hline $\begin{array}{c}\text { Nr of } \\
\text { Participants }\end{array}$ & \multicolumn{1}{c|}{ Age Group } \\
\hline- & $20-25$ \\
\hline- & $26-30$ \\
\hline 2 & $31-35$ \\
\hline 4 & $36-40$ \\
\hline 4 & $41-45$ \\
\hline 2 & $46-50$ \\
\hline 1 & $51-55$ \\
\hline- & Above 55 \\
\hline 13 & Total \\
\hline
\end{tabular}

Table 6. Distribution of Participants by Gender

\begin{tabular}{|c|c|}
\hline Gender of Participants \\
\hline Women & 4 \\
\hline Men & 9 \\
\hline Total & 13 \\
\hline
\end{tabular}

The inductive method was used for data analyses. To this end, the basic steps suggested by Creswell were used: preparing and arranging data for analysis, reading all data, coding data, and obtaining themes and descriptions from data (Creswell, 2008, p. 185).

The following methods were used to ensure trustworthiness of the study, and all data collected is stored: triangulating data, describing the field/scope and time of research, receiving consent from participants, voice-recording in interviews, and asking subject-area experts to check data for consistency and confirmation (Glesne, 2013, p. 65; Miles, et al., 2014, p .311).

Ethical principles such as confidentiality, responsibility, honesty and fairness are of particular importance in scientific research. These ethical principles were observed during the process of this research (McKernan, 1996; Uzuner, 2005). Some measures were taken to ensure compliance with ethical principles. All participants interviewed were provided with preliminary information on purpose, research questions, scope and methodology of the study. After this, an appointment was requested from potential participants to conduct semistructured interviews on a voluntary basis. All participants were informed that the data would be used solely for research purposes, and that they could withdraw from the research at any time. Written and oral consent was received from all participants to confirm that they participated in the research voluntarily. The interviews were voice recorded to avoid any loss of data. Written and oral approval was received from all participants to provide evidence that they consented to voice recording. Special attention was paid to ensure that the participants' names are kept anonymous in the research, and codes were used instead of real names. Oral permission was received from related departments for observations. As the documents obtained from the participants are confidential, the research report includes no visual materials related to these documents.

Some limitations apply to this study. First, the study is limited to group A ground service organizations, catering organizations, and terminal organizations operating in Turkey, and the Directorate General of Civil Aviation, i.e. the aviation authority in Turkey. Although 
each organization represented here is a large-scale one operating at the international level with thousands of employees, there is one authority responsible for SMS in each organization and the number of SMS experts is thus limited. The small number of participants is one of the limitations of the study. There are various limitations associated with semi-structured interviews, i.e. the primary data-collecting method in the study. The voice recorder, used in all semi-structured interviews to avoid loss of data, constitutes a limitation, as it prevents participants from expressing their ideas comfortably. Furthermore, another primary datacollecting tool in the study is limited to observations that the researcher made in SMS-related meetings and notes taken in these meetings. The secondary data-collecting method, i.e. examination of related documents, is restricted to materials such as SMS-related booklets, posters, manuals, questionnaires or software, and the research diary kept by the researcher.

\section{FINDINGS AND INTERPRETATION}

\subsection{The Process of Transition to SMS}

The ICAO requires member states to launch and implement the State Safety Program (SSP), to ensure that affiliated service providers implement SMS, and to audit the implementation of SMS (ICAO, 2009, p. 6-2; 2013b, p. 3-1). The SSP, i.e. the Safety Management System implemented by states, requires states to regulate and implement appropriately the framework of SMS, which comprises four main components and twelve elements. SMS and SSP have separate frameworks which complement each other (DGCA, 2011, p. 11-3). The DEP, similar to SMS implemented in organizations, ensures that SMS is implemented under the auspices of the national aviation authority. At this point, the following concepts are of particular importance: the acceptable level of risk, i.e. risk as low as reasonably practicable (ALARP) (ICAO, 2009, p. 5-4), and the acceptable level of safety (ALOS). It is relative to define which safety risks are reasonable and acceptable, and requires carefully conducted cost-benefit analyses (DGCA, 2011, p. 5-4; ICAO, 2009, p. 5-4). Aviation organizations conduct risk analyses to identify which operations pose risks at the acceptable level and which operations include threats that constitute safety risks, and take measures to reduce safety risks and to lower high risks to the acceptable level, with the ultimate aim of improving safety. States have liabilities concerning the ALOS, the acceptable level of safety (ICAO, 2009, p. 6-2-5). By means of the SSPs they launch, states audit the operations of service providers, and take steps to ensure the ALOS in safety performance throughout the country in cooperation with the organizations.

Turkey is one of the states that is party to the agreement founding the ICAO. Thus, the country has taken the steps required for the implementation SMS in line with the framework defined by the ICAO. In Turkey, the Directorate General of Civil Aviation (DGCA) is the authority responsible for the implementation of SMS. The DGCA entirely adhered to the model proposed by ICAO for the implementation of SMS, adopted the model consisting of four main components and twelve elements, the outlines of which were drawn by ICAO, and asked national organizations to implement safety management system according to these outlines defined in the translation into Turkish of safety management manual, directives and regulations (DGCA, 2011; 2012b; 2012c). To this end, the DGCA issued some legislative instruments that directly affect aviation organizations, including "Ticari Hava Taşıma İşletmeleri Uçuş Eğitim ve Bakım Kuruluşlarında Emniyet Yönetim Sisteminin Uygulanmasına İlişkin Talimat (Directive on the Implementation of Safety Management System in Commercial Air Transport Companies, and Flight, Training and Maintenance Organizations)", "Hava Seyrüsefer Hizmet Sağlayıcıları Tarafından EYS Kullanılmasına İlişkin Talimat (Directive on the Use of SMS by Air Transport Service Providers)", "Sivil 
Havacılıkta EYS Yönetmeliği (Regulations on SMS in Civil Aviation)", and "Havalananlarında EYS'nin Uygulanmasına Yönelik Talimat (Directive on the Implementation of SMS in Airports)". With these instruments, the DGCA has obliged aviation organizations in Turkey to implement SMS since 2012.

The first findings of the research is that all aviation organizations included in the scope of this study initiated the process of transition to SMS after the issuance of related directives by the national authority, and took the first steps to implement SMS with the urge to comply with the legislation. This is apparent in the statements of P10 and P11, i.e. "... we initiated it when it became obligatory with the regulations of the Directorate General of Civil Aviation", and P9, i.e. "We got engaged in it because there was an obligation". In sum, the process of transition to SMS in aviation organizations started and continued with the triggering effect of the ICAO at the international level and the DGCA at the national level.

\subsection{Factors that challenge and facilitate the process of transition to SMS}

\subsubsection{Factors That Challenge the Process}

The legislation is ambiguous: It was found out that the main factor that challenges the transition process was the difficulties related to legislation. These difficulties may be classified as follows; the qualifications expected from SMS units and SMS experts are ambiguous, the legislation on SMS is highly general, the national legislation related to SMS is a translation of texts in foreign language, and it is not original, and all these factors cause ambiguities in practice.

P1 said the following about the fact that the legislation is not original: "... the directives and regulations are not original... That is why we have some difficulty in putting them into practice." It was also found out that the qualifications required from SMS experts are not clarified, and that this is a factor that affects the success of SMS. P4 explained this factor as follows: "One of the flaws I notice is this: It is a condition to have a security manager in all ground services or catering companies. There is a need to establish a unit in each service provider. However, there is not such condition about SMS. SMS is under the responsibility of any person... of quality managers in most cases. SMS is completely related to safety. There is a need for infrastructure. There is a need for an administrative unit that is to manage the infrastructure. There is a need for a manager responsible for this. Unfortunately, SMS does not have a clearly defined framework. I think the civil aviation authority should clearly define the details of safety unit and infrastructure it requires, and the actions to be taken in this unit. There is an ambiguity about it."

SMS is a novel and different practice: The participants argued that another challenge to the implementation of SMS derives from the fact that it is a novel approach and different from conventional approaches to safety management. This is summarized as follows by P9: "... because it is new and implemented for the first time, there are some ambiguities." What lies beneath this ambiguity is that SMS predicates on a new safety management paradigm. SMS, a product of performance-based approach that is seen as a new-generation management approach, differs from conventional methods and leaves organizations in a case of uncertainty where they do not know how to take measurement and prevention steps. Several participants drew attention to the fact that they did not know how to develop and employ predictive methods. "I have not used predictive methods before... Predicting an event before it does not provide any signs seems like an extremity. As you would acknowledge, we are not at the desired level about that. To be honest, we cannot anticipate the limits, but there is room for improvement in that area. Proactive, predictive... These are based on estimations without anything in hand. We had difficulty in taking risk assessment to ideal levels." Another 
uncertainty experienced by the participants is about how to measure safety performance within the scope of SMS. P3 explained this difficulty as follows: "In my opinion, the most difficult part is determining real performance indicators related to SMS. Everyone has difficulty in this. It overlaps with occupational health to a certain extent, with customers to a certain extent. It is related to fatality. Since SMS is associated with fatalities in minds, everyone in the sector, including us, has difficulty in developing Safety Performance Indicator (SPI) to measure the process that ensures the safety of direct operation in a sustainable way." The participant drew attention to the difficulty in developing parameters to measure safety within the frame of SMS, and summarized that there is an uncertainty about safety measurement in the sector.

SMS has remained on paper for now: All participants mentioned that it was easy to ensure compliance with SMS on paper, but it was challenging to put theory into practice. This is supported by P7, who reported to have "finished only developing the skeleton", and P4 who said the following: "This is what they asked us to do... Paperwork, documents... This is the truth. They want us to complete the paperwork to be audited, and this is what we did. But this is not the right thing.". This indicates that SMS is a system adopted by aviation organizations to ensure compliance with the legislation enforced by the national aviation authority, but organizations see it easier and more important to complete SMS procedures on paper because of audits and sanctions, rather than put them into practice. This understanding is one of the main causes that challenges the implementation of SMS.

Auditing is of ceremonial nature: This is a result of the finding that audits mostly remain on paper. Several participants stated that audits of the authority have so far remained on paper. The following is what P11 said about audits: "The audits mostly focused on papers rather than practices, I believe. We were asked whether the documentation was completed, what was included in which document... The auditing plan did not cover practices or examples of practices. Different types of auditing may be used in the practical aspect. You can go to the field to talk to employees, talk to the senior management, there may be various checkpoints in the organization. Then you can see whether SMS is really implemented or not." With his following statements, P8 also supports that auditing was not effective: "You can improve the effectiveness of auditing by focusing on business outcomes rather than theoretical experience. You can increase effectiveness and reduce conflicts when you see practices on site and talk to practitioners. If you ask questions based on a translated checklist, it is likely that you fail to understand the practice." Thus, different approaches adopted by theoreticians and practitioners in auditing decrease the effectiveness of audits, render it difficult to notice real-life equivalents of theories, and attribute a symbolic nature to auditing. Some participants also mentioned that not only audits of the authority but also internal audits in the organization sometimes remained as symbolic activities.

Organizations seek efficiency: Like other business corporations, aviation organizations seek efficiency in business. This is also seen in the implementation of SMS. While endeavoring to comply with the authority on one hand and seeking to ensure sustainability of efficiency on the other hand, aviation organizations have not allocated sufficient human resources for SMS, which challenged the implementation of SMS. One of the findings of this study, conducted with managers responsible for the launch and management of SMS in the organizations included in this study, is that the managers are responsible for SMS in addition to other duties. In no organization, there were units, managers and employees solely and specifically charged with the launch and implementation of SMS. However, a resource that was developed under the leadership of Federal Aviation Administration - FAA, which is a highly effective organization across the world, to guide the process of launching and implementing SMS recommends that large aviation organizations establish a unit that is 
specifically responsible for SMS (Transportation Research Board, 2009). Yet, P4 explained as follows that a specific and independent unit cannot be established unless it is obligatory: "...certainly, it cannot be otherwise. No one will allocate resources to it. As I told, 'there is a manager, why would I have another one,' they think. In sum, the largest resource and cost is related to human resources... They are not willing to bear such a cost... Do you think the company will bear the costs? A company never wants costs, extra costs." Another finding is that SMS is seen as an obstacle to the fulfillment of operational targets since timely flight operation is a priority in the sector. Therefore, intensive and fast flight operations cause a time pressure on personnel. It may be quite hard to implement SMS under real-life conditions, due to the concern for fulfilling operational activities on time. P2 explained this as follows: "There are competitive conditions as well as changing conditions in the sector. Let's take ground time, for example. Up to a couple of years ago, there were no 20-25 minutes of ground time. But now there is such a thing in our lives. We used to prepare the aircraft in a longer period of time without time pressure, in 45 minutes or one hour. But now the period is getting shorter. Particularly with the entry of low-cost companies to the sector, we have more time pressure, and thus we are not at the desired level in terms of safety culture and effective use of reporting mechanisms. For, people have to live fast, and operations need to be faster. Personnel may fail to report any dangers they experienced during the day because they cannot find time or they forget it at the end of day." Another related finding is the reluctance to allocate adequate financial resources. All organizations included in this study are business corporations that operate at the national and international scale. That is why their aim is to fulfill minimum requirements related to the implementation of SMS, and avoid any extra costs. P6 supports this finding with his following statements: "When there is a high-cost requirement related to SMS in $\mathrm{x}$ or $\mathrm{y}$ department, I am never told about this. OK, I am an SMS manager, but I do not go to $\mathrm{z}$ department to see what is happening there. It is the employees working in $\mathrm{z}$ department who know what is going on. They do not notify us about this. Not only us, but no one else, or even they notify someone, enterprises tend to ignore it if the cost is high... There is a need for a functioning reporting mechanism, but the manager of that department will probably not communicate it to others and try to solve it within the department. Thus, many problems will be ignored."

The effect of positive safety culture: Positive safety culture is a sine qua non for an effective SMS. Defined briefly as the combination of beliefs and values related to safety (Reason, 1998:294), positive safety culture may affect safety procedures by orientating decisions and acts of personnel in the organization (Stolzer et al., 2008, p. 24). In organizations, where personnel and senior managers have high safety commitment, it is more likely that hazards that compromise safety and measures that mitigate risk are sought, discovered and handled. There is not a positive safety culture in the organizations where not all employees uphold safety, the factors that are likely to cause hazards are ignored and not reported, such factors are disregarded by senior management even when reported by employees, and measures related to hazards are not taken. The success of SMS will certainly decrease in such organizations (Cabrera, 1997, p 267; Gill and Shergill, 2014; Gerede, 2015, p. 108). In the majority of organizations included in this study, it was found out that SMS practices were not adopted by all employees, and that organizational participation in practice was quite low. This is apparent in following statements of P4: "What challenges us most was that the personnel did not adopt SMS... For instance, I say that Mehmet is responsible for this, then no one else other than Mehmet is interested in procedures." Another factor that challenges the process is the lack of a reporting culture. The related findings of this study are that reporting does not comply with the culture of our country, people generally do not have a positive attitude to reporting because of either the fear of getting punished or the common perception that reporting may mean whistleblowing, and employees usually tend to report the 
cases that do not arise from their own or other personnel's mistakes, but from the mistakes of other organizations. The foregoing findings related to positive safety culture were observed in eight out of eleven organizations included in this study. The remaining three organizations reported that they had a large team taking part in SMS procedures and that they were satisfied with the number of related reports. These organizations pointed to the existing culture as the cause of positive reporting culture, and thus provided signs of the presence of a positive safety culture.

Sectoral issues: Certain issues related to nature of the sector also constitute a challenge to the implementation of SMS. One of these issues is that airport authorities do not take an active role in the implementation of SMS. The organizations included in this study provide services related to flight operations, and do not act in the airport. That is why they rely on the airport authority in terms of resources. This reliance implies that the organization is directly affected by any activities that an airport operator carries out or fails to carry out. All participants argued that airport operators have so far failed to establish an umbrella system that encompasses all stakeholders and ensures information exchange between the stakeholders, and that such a system is a necessity in the sector. P12 explained as follows the problems related to airports and the dependence of flight operators on airport operators:

"Of course, there is an authority. Airports are not left without an authority, are they? Yet, there is a need for some sort of guidance from that authority. For, individual attempts are always limited. This is what we encounter in many attempts: For instance, there is a risk, this risk affects many people, and how can we eliminate this risk? An investment of the airport authority can make such and such changes there. We operate in such a structure. You already know how we work. We operate according to licenses that airport operators grant under certain conditions. We have no more authorities, for example no authority about any infrastructural changes in xxx part of the airport. We can just make an official request. But the decision-making mechanism is the authority that grants us the license. That authority has to establish an organization of coordination for such changes. The airport authority... I especially want to highlight this because we encounter lots of problems about it." There are some other obstacles to the implementation of safety-enhancing measures. It takes airport authorities a lot of time to implement risk-mitigating cautions and that heavy bureaucratic procedures cause a delay in taking risk-mitigating cautions related to the infrastructure of airports. This is explained by P1 and P2 as follows: "Impossibilities are mostly related to the infrastructure in Turkey. There are some hazards, some activities that cause risk in the sector. We observed and detected them. However, when we share them with the authority, we cannot get an outcome in a fast way. There are some impossibilities in practice. Everybody has already agreed on risks related to the problem. 'Yes, there is such a risk, such a hazard here. And this will produce such results,' we can say. But we have a difficulty in obtaining results. It sometimes is not easy to go beyond the airport authority or the bureaucracy... We ask them to do something, but they refuse. 'So let us do this.' 'No,' they say. We have to operate under those risks until they say yes, they take a step." In addition to the problems related to the airport authority, there are some other problems, including the lack of coordination between the DGCA and airport operators, which constitutes an obstacle to the elimination of risks that compromise safety and leaves problems unsolved. Other challenges that affect the implementation of SMS are time pressure and sharing the working area with other organizations. A single flight operation in the airport requires the service of several organizations in a limited period of time. In addition to time pressure, working with different organizations brings about new risks. P12 explained as follows how this sectoral issue affects their operations: 
"There are some difficulties we encounter because of some issues specific to the sector. One of them is sharing the working area. Imagine this: The aircraft landed, it is in parking position. The engine are turned off, the lights are off. You have 20-25 minutes for ground handling, catering services, fueling and so on. All these need specific techniques, you may have some extra needs... You work in such an atmosphere. In this atmosphere, all companies must be able to speak the same language, but they do not. For example, there are temporary parking positions just near aircrafts. You probably saw when boarding. There is a competition for taking the first place. For instance, the fueler brings his vehicle first. Then the caterer comes and does his job without looking around. The tractor drives away. They do not think whether they cause risks for others when doing their job. There is no collaborative thinking. As I have already said, because of time pressure, people just concentrate on their own job." P7 talked about his relevant experience as follows: "How can you implement SMS when there are about 160-170 thousand passengers during on-peak hours in summer? Let me give you an example. In airports, we have rules about SMS or safety. What is the first rule? Speed limit is 25 kilometers. Do you see any vehicles complying with the speed limit here? These companies have all adopted SMS. How many vehicles traveling at $25 \mathrm{~km}$ can you show me? There are no, because operation must be fast. They have to be fast."

The challenges discussed here and supported with direct quotations from participants are obstacles to the implementation of SMS. Several sectoral issues make it difficult to put SMS into practice, including time pressure, growing air traffic, need for cooperation with several organizations, infrastructural problems, bureaucratic obstacles, the failure of airport operators in developing practices that encompass all organizations operating in the airport, and communication problems between the DGCA and airport operators

\subsubsection{Factors That Facilitate the Process}

Presence of legislation: The DGCA forced aviation organizations in Turkey to implement SMS, and issued the legal instruments required to ensure the implementation of SMS. These were the steps that initiated the SMS process in Turkey. Aviation organizations shape the structure and activities related to SMS in line with the legislation. The majority of participants reported that they took the legislation as a model for SMS processes, and made use of the ICAO documents in addition to the legislation adopted by the DGCA. The participants mentioned that they took the legislation as a reference when building the system, and developed structures and processes based on the legislation. Despite the ambiguities and deficiencies related to the legislation, the participants see the presence of legislation as an advantage for implementing SMS.

Implementation of SMS in other organizations: Aviation organizations, functioning within the same institutional framework, have started implementing SMS with similar mechanisms, and attempted to comply with requirements in the legislation. In these attempts, the organizations have seen each other as a reference, and not only inquired but also modeled the related activities of other organizations. This was summarized as follows by P10 "There was also the data we obtained from the companies we contacted. We partially made use of that data", and P8 "We learned a lot from friends on the same platform... For example, we shared with each other the presentations we used in trainings". It may be concluded that the cooperation between the organizations facilitated the SMS process, and rendered SMS more comprehensible.

SMS trainings: There is a need for a safety training program to ensure that all staff have thorough knowledge of and are able to implement SMS. Each training must be designed based on the roles that staff play in safety. These trainings must be provided in the orientation process, specific to job description, and in repetitive cycles. Such training programs assume a 
significant role in teaching and implementing SMS. The findings of this study also draw attention to the importance of SMS training. Another source of reference that the participants found useful was trainings that the legislation required organizations to offer after they adopted SMS. The participants reported that they started understanding SMS in these trainings, and had recourse to the trainer and training documents to get support after trainings were completed. The participants agreed that training programs and trainers facilitated the process of transition to SMS, as stated by K10 "In the beginning, we were in contact with the trainer who gave us SMS training... We wanted support from him/her because he/she taught us what SMS is", and by K10 "We received a training on SMS in civil aviation... We got documents and presentation materials from the trainer. We use them as a reference in our SMS trainings".

Positive interaction between the sector and the authority: Most of the participants drew attention to the authority's attitude towards the implementation of SMS and its guiding role in the process. The majority of the participants reported that the DGCA was cooperative and open to interaction and exchange of information in the process of implementing SMS. It was important that the DGCA brought together aviation organizations in SMS workshops and seminars in order to discuss challenges and exchange information related to SMS, and to reduce uncertainties in the minds of practitioners. The data from the participants suggests that these information-providing activities were found satisfactory in the sector, and were useful for clarifying the ambiguities related to SMS. This is explained as follows by P12: "The DGCA has goodwill about this, and we can see its implications. It takes opinions from companies in the sector, and revises the directives in consideration of these opinions. There is no problem about this", and by P5: "Whenever we called them and asked something, they did their best to provide information about SMS. They are very positive." P8 supports the positive attitude of the DGCA with the following statements: "Conflicts sometimes arise, but they can be solved easily. I have to mention that the civil aviation authority is not the grim-faced "state institution' that we used to encounter in the past, it is now motivating and guiding."

Implementation of other management systems: Another factor that facilitated the process was the implementation of other management systems. Other systems contributed to the implementation of SMS, and in some cases, provided an infrastructure for building SMS. The participants reported to have taken the resources of similar systems as a reference in the implementation of SMS. P9 explained this as follows: "Because the infrastructure was similar to that of occupational safety, I made use of that infrastructure. Not only I but also our occupational safety expert... I used occupational safety as the infrastructure of SMS." P4 said the following to emphasize the contribution of other management systems and past experience to the implementation of SMS: "My previous experience was related to quality. ISAGO is a new standard. It is entirely an operational process, used to audit operational processes. I made use of it."

In brief, the main factors that facilitated the process of transition to SMS were the presence of legislation, the use of experience of other organizations, training programs concerning SMS, positive interaction between the sector and the authority, and the use of similar managements systems (e.g. occupational health and safety management system, OHSAS, ISAGO) implemented before SMS was adopted.

\section{CONCLUSION AND RECOMMENDATION}

This study has set out to explain the process of transition to SMS in Turkey and the factors that challenge and facilitate the transition process. The analyses of qualitative data produced some relevant results. The first finding is that the process started with the regulations and directives issued by the ICAO at the international level and the DGCA at the 
national level, and that aviation organizations in Turkey have implemented SMS since 2012 because of the obligation imposed by directives. The factors that challenge and facilitate the transition process, defined in response to the second research question, are provided in Table 7.

Table 7. The Factors That Challenge and Facilitate the Implementation of SMS

\begin{tabular}{|l|l|}
\hline \multicolumn{1}{|c|}{ Challenging Factors } & \multicolumn{1}{c|}{ Facilitating Factors } \\
\hline Ambiguity in legislation & Presence of legislation \\
\hline Novelty and difference of SMS & Implementations of other organizations \\
\hline SMS is implemented on paper for now & SMS trainings \\
\hline Organizations seek efficiency & $\begin{array}{l}\text { Positive interaction between sector and } \\
\text { authority }\end{array}$ \\
\hline Effect of positive safety culture & Other safety management systems \\
\hline Sectoral issues & \\
\hline
\end{tabular}

The findings of this study mostly support the results reported in the literature. The study presents findings consistent with the literature, particularly with regard to the understanding of efficiency adopted in organizations, the effect of positive safety culture on SMS, and the relationship between the sector and the authority (Gill, 2004; Gill and Shergill, 2004). The findings regarding the significance of positive safety culture and the role of authority also support the results of Gerede's $(2014 ; 2015)$ research on the implementation of SMS in aircraft maintenance organizations.

This study provides some recommendations to prevent any SMS-related problems and to improve the process of transition to SMS. First, there are some steps that must be taken by the civil aviation authority in order to eliminate the ambiguities. It will be particularly useful to provide a source of reference that includes practices related to Turkey and to adapt the legislation into the Turkish culture (the current manual is a translation), to develop the SMS legislation in a way to ensure that it provides models specific to organizations' fields of activity, to develop safety measurement indicators that are specific to organizations' fields of activity, and to clarify the qualifications that SMS units and personnel are required to have. SMS-related activities may be of secondary importance because SMS managers, in most cases, have other responsibilities and duties in addition to SMS, and units specific to SMS have not been established yet. That is why there is a need to clarify the qualifications of SMS units, managers and personnel. The establishment of separate SMS units is important especially in large organizations directly involved in flight operations. Excessive workload in busy airports, particularly in summer months, may constitute an obstacle to the implementation of SMS. Thus, appointing managers solely responsible for SMS will eliminate the dilemma of operation and safety. It is important that the roles and qualifications of SMS managers are defined clearly, and they are able to work independently. It was found out in this study that the authority adopted a cooperative attitude with regard to the implementation of SMS. Particularly workshops and training programs held by the authority were reported to be satisfactory by the participants. Given that they provide practitioners with the opportunity to eliminate ambiguities and discuss the problems, increasing the number of such activities will contribute to the process. Considering that the authority currently audits only what is on paper and cannot measure the results of real-life practices, there is a need to develop auditing tools that not only measure the documentation, but also practical implications of documentation. Since SMS may be confounded with other management systems, it is also important to conduct a study that defines the similarities and differences between SMS and existing management systems in organizations. Airport operators should 
set up an SMS that comprises all stakeholders in airports, and take an active role in order to remove bureaucratic barriers and regulate the coordination between stakeholders. This is likely to improve the success of SMS. It is also necessary to identify the risk arising from sharing the working area (in most cases, the ramp area) with other organizations, and airport operators are required to develop active solutions to this problem. The findings further suggest that there are infrastructure deficiencies in both organizations and the authority. Thus, there is a need for steps to be taken to determine and eliminate these deficiencies. Lastly, stronger communication that removes bureaucratic barriers between the civil aviation authority and organizations is likely to facilitate the process of implementing SMS.

\section{REFERENCE}

Ary, D.; Jacobs, L. C.; Sorensen, C.; Razavieh, A. (2010). Introduction to research education (8 b.). USA: Wadsworth Cengage Learning.

Berg, B. (2001). Qualitative research methods for the social science (4. bask1). USA: A Pearson Education Company

Cabrera, D. D.; Isla, R.; Vilela, L. D. (1997). An Evaluation of Safety Climate In Ground Handling Activities. Avitation Safety: Human Factors, System Engineering, Flight Operations, Economics, Strategies, Managements. (Ed: H. M. Soekkha). Netherlands: Ridderprint

Creswell, J. W. (2008). Research design: qualitative, quantitative and mixed methods approachs (3. bask1.). Sage Publication.

Creswell, J. W. (2013). Araştırma deseni: nitel, nicel ve karma yöntem yaklaşımları. (Çev: S. B. Demir.) Ankara: Eğiten Kitap.

Detra, Z. (2006). The legitimacy of the international civil aviation organization's universal safety oversight audit programme. Montreal: Institute of Air and Space Law Faculty of Law McGill University.

Directorate General of Civil Aviation. (2011). Emniyet yönetimi el kitabı. Ankara

Directorate General of Civil Aviation. (2012b). Havaalarında emniyet yönetim sisteminin ugulanmasina ilişkin talimat.

Directorate General of Civil Aviation. (2012c). Sivil havacılıkta emniyet yönetim sistemi yönetmeliği. Resmi Gazete: 28172

Federal Aviation Administration (2004). Safety Management System Manuel. Version 1.1.

Gerede, E. (2014). Challenges in implementation of the safety management system in aircraft maintenance: a qualitative analysis. 18. World Air Transport Research Conference' da sunulan bildiri. Bordeaux, France.

Gerede, E. (2015). A study of challenges to the success of the safety management system in aircraft maintenance organizations in turkey. Safety Science, 73, 106-116.

Gill, G. K. (2004). Perception of safety, safety violation and 1mprovement of safety in aviation: findings of a pilot study. Journal of Air Transportation, 9(3).43-55.

Gill, K. G. ve Shergill, G. (2004). Perceptions of safety management and safety culture in the aviaiton 1ndustry in new zealand. Journal of Air Transport Management, 10, 233-239.

Glesne, C. (2013). Nitel araştırmaya giriş (3 baskı). (Çev: A. Ersoy ve P. Yalçınoğlu) Ankara: Anı Yayıncilık. 
Hays, D. ve Singh, A. (2012). Qualitative inquiry in clinical and educational settings. New York,: The Guilford Press.

International Civil Aviation Organziation. (2006). Safety management manual (1. bask1). Montreal.

International Civil Aviation Organziation (2009). Safety management manual (2. bask1). Montreal.

International Civil Aviation Organziation (2013a). Safety management manual (3. bask1). Montreal.

International Civil Aviation Organization (2013b). Annex 19. Safety Management(1). Montreal

Liou, J. H.; Yen, L.; Tzeng, G. (2008). Building an effective safety management system for airlines. Journal of Air Transport Management, 20-26.

Maher, S. T.; Long, G. D.; Cromartie, R.S.; Sutton,I. S.;Steinhilber, M. R. (2013). Paradigm shift in the regulatory application of safety management systems to offshore facilities. Process safety progress.

McDonald, N.; Corrigan, S.; Daly, C.; Cromie, S. (2000). Safety management systems and safety culture in aircraft maintanence organizations. Safety Science , 34, 151-176. 4 2013 tarihinde alınd 1

McKernan, J. (1996). Curriculum action research: A handbook of methods and resources for the reflective practitioner (2. bask1). Kogan Page.

Merriam, S. (1998). Qualitative research and case study applications in education: revised and expanded from case study research in education. San Franciso: Jossey Bass.

Miles, M.; Huberman, A.; Saldana, J. (2014). Qualitative data analysis (3. bask1). USA: Sage Publication.

Patton, M. (2002). Qualitative research and evaluation methods. California: Sage Publication.

Perrow, C. (1984). Normal accidents; living with high risk technologies. USA: Basic Books.

Stake, R. (2010). Qualitative research: studying how things work. New York: The Guilford Press.

Stolzer, A. J.; Halford, C. D.; Goglia, J. (2008). Safety management system in aviation. England Publishing Company : Ashgate.

Transportation Research Board. (2009). ACRP: Safety Management Systems for Airport. FAA, Washington

Uzuner, Y. (2005). Baş makale: özel eğitimden örneklerle eylem araştırmaları. Ankara Üniversitesi Eğitim Bilimleri Fakültesi Özel Ĕ̆itim Dergisi, 6(2), 1-12. 